\begin{tabular}{|c|c|c|c|c|}
\hline $\begin{array}{c}\text { 118SHARE: SOCIAL WORK } \\
\text { JURNAL }\end{array}$ & VOLUME: 7 & NOMOR: 1 & HALAMAN: $1-129$ & $\begin{array}{l}\text { ISSN:2339 -0042 (p) } \\
\text { ISSN: 2528-1577 }(e)\end{array}$ \\
\hline
\end{tabular}

\title{
PRAKTIK BEKERJA BERSAMA KELOMPOK UNTUK PENGUATAN PROGRAM PELATIHAN DAN PENGEMBANGAN
}

\author{
Oleh: \\ Hery Wibowo ${ }^{1}$ \\ 1. Departemen Kesejahteraan Sosial Universitas Padjadjaran
}

Email:

hery.wibowo@unpad.ac.id

\begin{abstract}
Abstrak
Metode bekerja bersama kelompok (social group work) pada konteks pekerjaan sosial adalah sebuah praktik yang bertujuan untuk meningkatkan keberfungsian sosial, yang dilakukan melalui media kelompok. Sejauh ini, praktik bekerja bersama kelompok lebih banyak dikenal untuk tujuan pertolongan klien yang memiliki masalah khusus seperti ketergantungan narkoba, depresi, konsep diri rendah dan sebagainya. Hal ini wajar, mengingat praktik bekerja bersama kelompok memang memiliki sejumlah keunggulan, yaitu antara lain penggunaan prinsip-prinsip universalitas, rekonstruksi kognitif, penerimaan, serta alturisme, dimana klien cenderung merasa nyaman dan diterima, sehingga mampu pada akhirnya mengungkapkan permasalahan yang dialaminya, serta bahkan mampu memberikan saran-saran kepada anggota kelompok lainnya.

Makalah ini akan mengupas lebih dalam tentang praktik bekerja bersama kelompok (social group work) dalam kontek pelatihan dan pengembangan sumber daya manusia, baik di perusahaan, organisasi swasta maupun aparatur sipil negara. Prinsipnya, tulisan ini juga dimaksudkan untuk membedah tujuan pengembangan dari praktik bekerja bersama kelompok, disamping tujuan pengobatan/penyembuhan. Maka, secara lebih jauh akan dikupas beragam praktik bekerja bersama kelompok yang dikhususkan untuk tujuan pengembangan sikap, etos kerja, semangat untuk berprestasi maupun tekad untuk menampilkan yang terbaik pada bidang pekerjaan.
\end{abstract}

Key words: kelompok, pekerjaan sosial, pelatihan, pengembangan 


\section{Pekerjaan Sosial}

Praktik pekerjaan sosial, terus mengalami perkembangan, baik dari sisi teoritis maupun praktis. Menurut (Pujileksono, 2016) Kesejahteraan sosial sebagai suatu proses atau usaha terencana merupakan kegiatan yang mencakup peningkatan kualitas kehidupan, pemberian layanan sosial dan tunjangan sosial. Peningakatan kualitas kehidupan, pada konteks ini berlaku luas dan menyeluruh. Terdapat tiga pandangan umum dari tujuantujuan umum pekerjaan sosial (Payne, 2014) yaitu pandangan pemberdayaan, pandangan pemecahan masalah dan pandangan perubahan sosial. Prinsipnya, pekerjaan sosial merupakan bentuk pekerjaan yang berupaya meningkatkan beragam dimensi atau kualitas kehidupan manusia.

Lahan praktik dari pekerjaan sosial sangat luas dan multi dimensi. Salah satu lahan praktik yang penting adalah pada lembaga pelayanan sosial. Pengelolaan kelembagaan atau organisasi, seperti yang pada umumnya dilakukan, memerlukan pemahaman khusus tentang manajemen, atau lebih khusus lagi manajemen sumber daya manusia.

(Hardina, ., Middleton, Montana, \& Simpson, 2007) melalui kajian mereka tentang pendekatan penguatan pada organisasi pelayanan sosial, bahwa salah satu prinsip penguatan yang perlu dipertimbangkan adalah mendorong penggunaan pembangunan tim (tim building) dan kolaborasi diantara anggota organisasi. Kajian ini menguatkan arus utama yang berlaku, yaitu bahwa konsentrasi pengembangan aset perusahaan, adalah pada optimalisasi potensi individu di perusahaan.

Salah satu bentuk atau usaha optimalisasi potensi sumber daya manusia adalah melalui training. Training, didefinisikan (Lall \& Sharma, 2009) sebagai akuisisi dari pengetahuan, keterampilan dan kemampuan melalui program pengembangan professional. Program Pelatihan dan Pengembangan, secara bergantian dan sistematik terus dilakukan oleh perusahaan untuk mendorong peningkatan potensi karyawannya. Pelatihan merupakan hasil dari motivasi dari luar, sedangkan program pengembangan kebanyakan merupakan hasil dari motivasi internal (Lall \& Sharma, 2009).

Secara umum (Lall \& Sharma, 2009) tujuan dari program Pelatihan dan Pengembangan adalah sebagai berikut:

1. Tujuan Individual (mendorong karyawan dalam mencapai tujuan pribadinya, dimana pada gilirannya, dapat meningkatkan kontribusinya pada perusahaan)

2. Tujuan Organiasasi (membantu kemajuan organisasi, dengan mendorong efektivitas kerja dari masing-masing individu)

Berbasis penuturan di muka, maka jelaslah bahwa diperlukan strategi khusus untuk mencapai hal tersebut. Beragam metode atau strategi, sangat pantas dicoba dan diperjuangkan demi mendapatkan hasil terbaik. Kombinasi dari berbagai model peningkatan kapasitas, juga perlu untuk dilakukan.

Namun demikian, berdasarkan kajian dari metode training juga belum dapat menyelesaikan seluruh persoalan peningkatan potensi karyawan. Artinya, dibutuhkan pendekatan-pendekatan lain yang lebih mampu untuk mengoptimalkan seluruh sumber daya yang ada, sekaligus mengoptimasi dinamika interaksi sosial yang telah terbangun. 


\begin{tabular}{|c|c|c|c|c|}
\hline $\begin{array}{c}\text { 118SHARE: SOCIAL WORK } \\
\text { JURNAL }\end{array}$ & VOLUME: 7 & NOMOR: 1 & HALAMAN: $1-129$ & $\begin{array}{l}\text { ISSN:2339 -0042 }(p) \\
\text { ISSN: } 2528-1577 \\
(e)\end{array}$ \\
\hline
\end{tabular}

Tabel 1

Aspek Utama dari Sistem Klien Mikro dan Makro

(Poulin, 2005)

\begin{tabular}{|c|c|c|c|c|}
\hline System Level & Client System & $\begin{array}{l}\text { Purpose of Helping } \\
\text { Relationship }\end{array}$ & Use of Self & Intervention \\
\hline $\begin{array}{l}\text { Micro } \\
\text { Individual } \\
\text { Family } \\
\text { Group }\end{array}$ & $\begin{array}{l}\text { Individual } \\
\text { Couples families } \\
\text { Small groups }\end{array}$ & $\begin{array}{l}\text { Enhance functioning } \\
\text { Empowerment }\end{array}$ & $\begin{array}{l}\text { Understanding } \\
\text { Sensitivity } \\
\text { Respect } \\
\text { Acceptance } \\
\text { Empahty } \\
\text { Cooperative } \\
\text { intentions } \\
\text { Hopefulness } \\
\text { Partnership } \\
\text { Support } \\
\text { Commitment } \\
\text { Confidence } \\
\end{array}$ & $\begin{array}{l}\text { Counseling } \\
\text { Supportive counseling } \\
\text { Education \& training } \\
\text { Case management } \\
\text { Service management } \\
\text { Service coordination } \\
\text { Service negotiation } \\
\text { Resource mobilization } \\
\text { Client advocacy }\end{array}$ \\
\hline $\begin{array}{l}\text { Macro } \\
\text { Organization } \\
\text { Community }\end{array}$ & $\begin{array}{l}\text { Agency leader } \\
\text { Agency task forces } \\
\text { Agency communities } \\
\text { Professional task } \\
\text { forces } \\
\text { Community } \\
\text { coalitions } \\
\text { Neighbourhood } \\
\text { groups }\end{array}$ & $\begin{array}{l}\text { Improve } \\
\text { organization } \\
\text { Improve services } \\
\text { Develop services } \\
\text { Improve community } \\
\text { conditions } \\
\text { Empower residents } \\
\text { Develop community } \\
\text { resources } \\
\text { Increase citizen } \\
\text { awareness } \\
\text { Mobilize citizen }\end{array}$ & $\begin{array}{l}\text { Understanding } \\
\text { Sensitivity } \\
\text { Respect } \\
\text { Acceptance } \\
\text { Empahty } \\
\text { Cooperative } \\
\text { intentions } \\
\text { Hopefulness } \\
\text { Partnership } \\
\text { Support } \\
\text { Commitment } \\
\text { Confidence }\end{array}$ & $\begin{array}{l}\text { Education and Training } \\
\text { Program Planning } \\
\text { Community } \\
\text { Development }\end{array}$ \\
\hline
\end{tabular}

\section{Bekerja Bersama Kelompok}

Terdapat sejumlah hal yang menarik bagi para praktisi untuk mengaplikasikan praktik bekerja dalam kelompok (Zastrow, 1995). Artinya, selalu terbuka peluang untuk perluasan aplikasi dari praktik bekerja bersama kelompok. Metode bekerja dengan kelompok (social group work), adalah sebuah metode pekerjaan sosial yang menggunakan media kelompok sebagai instrument pertolongan.

Olmstead, dalam (Zastrow, Social Work with Groups, 1987) menyatakan kelompok sebagai a plurarity of individual who are in contact with one another, who take one another into account, and who are aware of some significant commonality. An essential feature of a group is that its members have something in common and that they believe that what they have in common make a difference.

Perlman dalam (Ferguson, 1963) menjelaskan bahwa social casework adalah sebuah proses yang digunakan oleh sejumlah agen kesejahteraan sosial untuk membantu individu untuk mengatasi masalah/beradaptasi secara lebih efektif dalam keberfungsian sosialnya.

Metode bekerja dengan kelompok (groupwork) dan bekerja dengan individu (casework) merupakan dua metode yang dapat digunakan untuk membantu individu, meningkatkan keberfungsiannya dan keberdayaannya (Poulin, 2005). Salah satu tantangan pekerjaan sosial sekaligus keunggulannya, adalah bahwa pekerja sosial menggunakan dirinya sebagai instrument. Prinsipnya, membangun hubungan 
interpersonal yang baik, mutlak diperlukan. Artinya lagi, melalui interaksi interpersonal, dapat tercipta hal-hal yang mengarah pada perbaikan kualitas hidup. Dua hal penting terkait faktor kontekstual yang berdampak pada kebanyakan pekerja sosial adalah bagaimana lahan praktik (setting) dikelola dan bagaimana mereka di supervisi (Shulman, 1991)

\section{Pendekatan Berbasis Kekuatan}

Praktik pekerjaan sosial menggunakan beberapa pendekatan. Salah satu yang sedang banyak digunakan adalah pendekatan berbasis kekuatan (Poulin, 2005). Berikut dua poin utamanya: Setiap individu, kelompok, keluarga dan komunitas memiliki kekuatan dan setiap lingkungan penuh dengan sumbersumber. Berbasis prinsip tersebut, terlihat bahwa hal yang perlu dipegang kuat adalah bahwa setiap individu seyogianya memiliki kekuatan. Namun belum tentu setiap kekuatan tersebut sudah dapat berkembang dengan baik.

Pada konteks pengembangan sumber daya manusia pada sebuah organisasi atau institusi tertentu, pendekatan berbasis kekuatan ini dapat digunakan sebagai landasan pijak untuk memulai praktik. Telah dipahami bersama bahwa saat ini, sumber daya manusia adalah aset terpenting bagi sebuah organisasi. Maka, tepat kiranya jika perlu selalu dihasilkan kajian-kajian yang menghasilkan metode/strategi terbaru bagi pengembangan sumber daya manusia. Metode Groupwork, sebagai salah satu metode pekerjaan sosial, dapat dipertimbangkan menjadi salah satu metode yang dapat dikombinasikan atau digabungkan dengan rangkaian proses pengembangan sumber daya manusia organisasi/perusahan.

Salah satu pola praktik yang khas dari Social Groupwork adalah mengedapankan aspek potensi dari klien, aspek keunggulan dan kelebihan dari klien. Singkatnya, klien diajak untuk mengingat dan melihat potensi positif terbaiknya untuk dikeluarkan. Artinya, melalui pendekatan yang tepat, klien dapat diajak untuk melihat keunggulan pribadinya dan juga keunggulan rekan satu timnya.

Lewis dalam (Doel, 2006) menyatakan bahwa pengetahuan merupakan bukti-bukti dari penelitian ditambah dengan kebijaksanaan hasil praktik ditambah dengan layanan pengguna dan pengalaman-pengalaman yang dibagikan. Prinsipnya, praktik bekerja dengan kelompok mementingkan banyak faktor, dimana salah satu faktor pentingnya adalah media dinamika kelompok yang memungkinkan terbangunnya rasa saling percaya.

Lahan dari psikologi positif (Selignman \& Csikszentmihalyi, 2000) adalah lebih fokus pada level subjektif (individu) adalah tentang pengalaman pribadi, kesejahteraan, kepuasa (di masa lalu), harapan dan optimism (di masa depan), dan aliran kebahagiaan (di masa sekarang). Pada level individu, kajian psikologi positif adalah lebih banyak tentang sifat (trait) individu; kapasitas untuk mencintai, keberanian, keterampilan internasional, kegigihan, kemampuan memaafkan, spiritualitas, dan kebijaksanaan. Gerakan ini mengajak para praktisi pengembangan sumber daya manusia untuk lebih fokus pada sisi humanis individu. Artinya, aspek individu sebagai salah satu komponen industri benar-benar diperhatikan.

Penggunaan Group Work, kiranya dapat dijadikan alternatif bagi metode ataupun strategi pengembangan sumber daya manusia dalam perusahaan/orgnaisasi. Hal ini mengingat bahwa metode ini memiliki sejumlah pedoman dasar untuk pijakan dari aplikasi tekniknya. Berikut adalah analisa teoritis dari aplikasi metode groupwork dalam kaitannya dengan strategi alternatif pengembangan sumber daya manusia organisasi. 


\begin{tabular}{|c|c|c|c|c|}
\hline $\begin{array}{c}\text { 118SHARE: SOCIAL WORK } \\
\text { JURNAL }\end{array}$ & VOLUME: 7 & NOMOR: 1 & HALAMAN: 1 - 129 & $\begin{array}{l}\text { ISSN:2339 -0042 }(p) \\
\text { ISSN: 2528-1577 }(e)\end{array}$ \\
\hline
\end{tabular}

\section{Tabel 2}

\section{Analisa Teoritis Metode Groupwork dan Pengembangan SDM Organisasi}

\begin{tabular}{|c|c|}
\hline Universality & $\begin{array}{l}\text { Beragam masalah kinerja seringkali menimpa kondisi internal individu. } \\
\text { Adanya wahana untuk saling bertukar pikiran, kesempatan untuk } \\
\text { didengarkan, dapat menjadi instrument yang baik untuk meredakan stress } \\
\text { kerja. Pengalaman mendengarkan berbagai kondisi dan permasalahan yang } \\
\text { berbeda-beda, yang dimiliki oleh peserta lain, dapat menjadi sebuah } \\
\text { masukan berharga pada diri sendiri; yaitu bahwa saya tidak sendiri } \\
\text { mengalami kondisi ini. } \\
\text { Perasaan ini adalah sesuatu hal yang penting mengingat terkadang individu } \\
\text { menganggap dirinya paling berat masalahnya. Prinsip universalitas ini } \\
\text { mendorong setiap individu dalam kelompok merasa 'tidak sendiri' } \\
\text { menghadapi berbagai permasalahan yang sedang dihadapai. Melaluinya, } \\
\text { individu diharapkan dapat mulai memupuk asa, akan kehidupan yang lebih } \\
\text { baik. }\end{array}$ \\
\hline Hope (harapan) & $\begin{array}{l}\text { Pada praktik bekerja dengan kelompok, terjadi banyak dinamika, } \\
\text { komunikasi dan juga proses saling mendukung dan menguatkan. Setiap } \\
\text { peserta, dapat melihat perubahan pola pikir, sikap maupun perilaku dari } \\
\text { peserta lainnya. Pengalaman melihat proses peserta lain berubah menjadi } \\
\text { lebih baik, dapat menjadi sebuah inspirasi bagi individu untuk melihat dan } \\
\text { mengintrospeksi dirinya. Artinya, proses yang terjadi dapat mendukung } \\
\text { tumbuhnya harapan akan kemungkinan perubahan pribadi yang lebih baik. }\end{array}$ \\
\hline Altruism & $\begin{array}{l}\text { Aplikasi Metode bekerja bersama kelompok (groupwork memungkinkan } \\
\text { setiap individu peserta merasa berharga, karena melalui media ini, masing } 2 \\
\text { individu memiliki kesempatan untuk memberikan arahan/nasehat/berbagi } \\
\text { pengalaman kepada peserta lainnya. Artinya, ada kemungkinan, sesuatu } \\
\text { yang diungkapkan tersebut dapat berguna dan bermanfaat bagi anggota } \\
\text { lainnya. }\end{array}$ \\
\hline $\begin{array}{l}\text { Cognitive } \\
\text { Resturcturing }\end{array}$ & $\begin{array}{l}\text { Salah satu keunggulan dari metode groupwork adalah kemampuannya } \\
\text { untuk mengubah pola pikir setiap pesertanya, tanpa paksaan. Dinamika } \\
\text { kelompok yang terjadi, memungkinkan setiap peserta meralat pendapat } \\
\text { pribadinya dan secara ikhlas menggantinya sesuai dengan konteks yang } \\
\text { dihadapi saat tersebut. } \\
\text { Sifat individu yang cenderung egois dan mementingkan pendapatnya } \\
\text { sendiri (Les Giblin), akan perlahan luntur melalui mekanisme social } \\
\text { groupwork. }\end{array}$ \\
\hline
\end{tabular}


Pola-pola pengembangan Sumber Daya Manusia di perusahaan, perlu selalu ditingkatkan. Paradigma bahwa manusia adalah aset terpenting bagi perusahaan, tentunya merupakan sumber energi ataupun daya dorong yang besar untuk selalu berpikir tentang peningkatan kualitas sumber daya manusia. Metode groupwork dapat menjadi salah satu alternatif pilihan model/strategi pengembangan sumber daya manusia di perusahaan.

\section{DAFTAR PUSTAKA}

Bridges, K. M. (2013). Factors Contributing to Juvenile Delinquency. Journal of Criminal Law and Criminology.

Burfeind, J., \& Bartusch, D. J. (2006). The Study of Juvenile Delinquency. In J. Burfeind, \& D. J. Bartusch, Juvenile Delinquency: An Integrated Approach (2nd ed., pp. 10-11). London: Jones and Bartlett Publisher International.

Carroll, A., Houghton, S., Durkin, K., \& Hattie, J. A. (2009). Adolescent Reputations and Risk. New York: Springer.

CB Magazine. (2014, July 21). Alumni SMAN 5 dan SMAN 20 Bandung Tawuran. Retrieved Maret 24, 2017, from cbmagazine.blogspot.co.id: http://cbmagazine.blogspot.co.id/2014/07/alum ni-sman-5-dan-sman-20-bandung.html

Curtis, A. C. (2015). Defining Adolescence. Journal of Adolescence and Family Heatlh, 7(2).

detikNews. (2013, Februari 19). Duh, Pelajar di Jabar Tertinggi Pengguna Narkoba. Retrieved Maret 24, 2017, from news.detik.com: http://news.detik.com/jawabarat/2173 861/duh-pelajar-di-jabar-tertinggipengguna-narkoba
Doel, M. (2006). Using Groupwork. Madison Ave New York: Routledge.

Ferguson, E. A. (1963). Social Work an Introduction. Philadelphia \& New York: Skidmore College J. B Lippincott Company.

Hardina, D., ., Middleton, J., Montana, S., \& Simpson, R. (2007). An Empowering Approach to Managing Social Service Organizations. New York: Springer Publishing Company.

Kim, H.-S., \& Kim, H.-S. (2008). Juvenile Delinquency and Youth Crime. New York: Nova Science Publisher.

Kompas.com. (2016, Desember 29). Ini 11 Jenis Kejahatan yang Menonjol Selama 2016. Retrieved Maret 24, 2017, from megapolitan.kompas.com: http://megapolitan.kompas.com/read/2 016/12/29/17470511/ini.11.jenis.kejah atan.yang.menonjol.selama.2016

Lall, M., \& Sharma, S. (2009). Personal Growth \& Traning \& Development. New Delhi: Excel Books.

Midgley, J. (1995). Social Development - The Developmental Perspective In Social Welfare. London: SAGE Publication Inc.

Payne, M. (2014). Modern Social Work Theory. Chicago, Illionis: Lyceum Book, Inc.

Poulin, J. (2005). Strenghts-Based Generalist Practice: A Collaborative Approach second edition. Belmont USA: Thompson Books/Cole.

Pujileksono, S. (2016). Perundang-undangan Sosial dan Pekerjaan Sosial: Perspektif Pemenuhan Keadilan \& Kesejahteraaan Sosial Masyarakat. Malang-Jawa Timur: Setara Press.

Rumini, S. (1997). Psikologi Pendidikan. Yogyakarta: UPP IKIP Yogyakarta. 


\begin{tabular}{|c|c|c|c|c|}
\hline $\begin{array}{c}\text { 118SHARE: SOCIAL WORK } \\
\text { JURNAL }\end{array}$ & VOLUME: 7 & NOMOR: 1 & HALAMAN: $1-129$ & $\begin{array}{l}\text { ISSN:2339 -0042 }(p) \\
\text { ISSN: } 2528-1577 \\
(e)\end{array}$ \\
\hline
\end{tabular}

Selignman, M. E., \& Csikszentmihalyi, M. (2000). Positive Psychology. American Psychologist, 55 no 1.

Shoemaker, D. J. (2013). JUVENILE DELINQUENCY. The Journal of Academic Social Science Studies, 578588.

Shulman, L. (1991). Interactional Social Work Practice: toward an empirical theory. Itasca Illinois: Peacock publisher, inc.

Siegel, L. J., \& Welsh, B. C. (2013). Juvenile Delinquency: The Core (4th ed.). New York: Cengage Learning.

Supriadi, Y. (2015, Agustus 14). Sepuluh Ribu Anak Kini Berhadapan Dengan Hukum. Retrieved Maret 24, 2017, from www.pikiran-rakyat.com: http://www.pikiranrakyat.com/bandungraya/2015/08/04/337054/sepuluh-ribuanak-kini-berhadapan-dengan-hukum

Suryanto, A. (n.d.). Juvenile Delinquency in Indonesia. Retrieved April 7, 2017, from drianyanto.wordpress.com: https://drianyanto.wordpress.com/201 1/03/21/juvenile-delinquency-inindonesia/

Zamrozik, A. (2009). Social Policy In The Post-Welfare State. australia.

Zastrow, C. (1987). Social Work with Groups. Chicago: Nelson-Hall Publisher .

Zastrow, C. (1995). The Practice of Social Work fifth edition. Pasific Grove California: Brooks/Cole Publishing Company. 